\title{
Operationalizing Iterative Risk Management under Limited Information: Fiscal and Economic Risks Due to Natural Disasters in Cambodia
}

\author{
Junko Mochizuki ${ }^{1} \cdot$ Soravit Vitoontus $^{2} \cdot$ Bandula Wickramarachchi $^{2}$ • \\ Stefan Hochrainer-Stigler ${ }^{1} \cdot$ Keith Williges $^{1} \cdot$ Reinhard Mechler $^{1}$ • \\ Ros Sovann ${ }^{3}$
}

Published online: 14 December 2015

(C) The Author(s) 2015. This article is published with open access at Springerlink.com

\begin{abstract}
Iterative risk management and risk-sensitive public investment planning are increasingly seen as essential elements of natural disaster resilience. This article assesses the disaster risk facing the hazard-prone Southeast Asian country of Cambodia and discusses its fiscal preparedness and need for proactive disaster risk management. The study provides a bottom-up assessment of flood and cyclone risks to public and private buildings including educational structures, health facilities, and housing and estimates the total direct economic damage to range from approximately USD 304 million for a 5-year return period event to USD 2.26 billion for a 1000 -year return period event. These estimates were further analyzed using the fiscal risk due to disasters, which indicates that Cambodia will likely face a resource gap whenever a hazard as large as that of a 28-year return period event strikes. Given the frequent occurrence of disasters and rapid accumulation of capital assets taking place, proactive risk reduction is highly advisable. But interviews with national policymakers also revealed that there are a number of barriers to effective risk reduction and management in Cambodia. The general lack of awareness regarding risk-based concepts and the limited availability of local risk information necessitate a continued and sustained effort to build iterative risk management in Cambodia.
\end{abstract}

Junko Mochizuki

mochizuk@iiasa.ac.at

1 International Institute for Applied Systems Analysis (IIASA), 2361 Laxenburg, Lower Austria, Austria

2 Asian Disaster Preparedness Center (ADPC), Bangkok 10400, Thailand

3 National Committee for Disaster Management (NCDM), Phnom Penh 12105, Cambodia
Keywords Cambodia $\cdot$ Fiscal impact $\cdot$ Iterative risk management - Macroeconomic impact - Natural disaster risk

\section{Introduction}

Fiscal preparedness for natural disasters and risk-sensitive public investment planning are increasingly seen as essential elements of natural disaster resilience (UNDP 2010; MichelKerjan et al. 2013; UNISDR 2013; AMCDRR 2014). In recent years, an increasing trend among the national and local governments of developing countries is to adopt proactive risk management strategies. For example, proactive risk reduction investments have been made possible through the use of the Fund for Natural Disasters (FONDEN) in Mexico since 2006 (GFDRR 2013). In the Philippines, the national calamity fund and the local disaster risk reduction and management fund (LDRRMF) have operated actively since 2012 (American Red Cross 2013). Analogous proactive policies are seen as necessary steps to counteract future challenges of climate change, continued urbanization, and economic development in high risk areas of many developing countries (IPCC 2012). Although globally there are encouraging trends, response-oriented disaster management is still dominant in many areas of the world, and much work remains to be done to promote proactive risk management.

Proper assessments of natural disaster risk are needed to encourage forward-looking, risk-sensitive investment decisions and development strategies. The important steps in these decisions include the identification and assessment of current and emerging risks, together with collective decisions to accept or manage risk through a number of means-including the design of national policy strategies and sectorial plans, the allocation of budgets to risk 
management, and the establishment of regulations to reduce natural disaster risk (Bettencourt et al. 2006). Ideally, such disaster risk management (DRM) decision making is performed in an iterative fashion that allows for continuous learning and course correction as new information becomes available (IPCC 2007). A recent IPCC report argues that "an iterative process of monitoring, research, evaluation, learning, and innovation can reduce disaster risk and promote adaptive management in the context of climate extreme (IPCC 2012, p. 17).”

Empirically, how iterative risk management can be implemented in practice remains largely unclear. Nor do we fully comprehend how the notion of "mainstreaming" can be carried out in reality. Policymakers are often faced with the practical issues of how their DRM decisions should be integrated into broader development strategies and how different agencies can work together given competing interests. The problem is also highly contextual, as Margareta Wahlstrom (2013, p. 49) of UNISDR writes:

Government officials that talk to us say that their institutional structures are not appropriate for disaster risk reduction because risk management in the framework of government is very low down in the hierarchy with little money and no authority to coordinate what other government departments do. Governments also claim they suffer from an inability to use all the available information. It is not that information is not accessible, the problem is how to process it. Governments want to be able to set targets and measure progress, but find there is not enough disaster risk reduction expertise.

With deep uncertainty about climate change outcomes, together with a general lack of reliable data in developing countries, it is easy to imagine that one of the biggest challenges to iterative risk management lies in the acceptance of uncertainty. Policymakers, practitioners, and academics alike must put faith in the proposition that learning and improved data will eventually bring workable solutions, even when evidence initially seems utterly insufficient. Instead of using the presence of uncertainty as the reason for inaction, the awareness of uncertainty should give momentum for further learning and capacity building. This article presents a study of risk assessment in Cambodia as an example of such iterative risk management at work, identifying some of the tangible barriers developing countries face in implementing such an approach.

Continued learning is an essential element of the DRM process because both the availability of risk information itself and the local capacity to interpret and make decisions based on such information are generally limited in Cambodia. Existing studies on disaster risk assessment in Cambodia are limited to a few vulnerability assessments
(Royal Government of Cambodia and WFP 2003) and only retrospective assessments (World Bank 2012; HochrainerStigler et al. 2014) with no forward-looking components have been conducted until now. Therefore the goal of this study was to compile a detailed national inventory of public and private buildings and perform an economic and fiscal risk assessment using bottom-up data on hazards, exposure, and vulnerability.

Our modeling results indicate that the total direct economic damage associated with floods and typhoons in Cambodia is higher than previously estimated. For a 5-year return period natural disaster event the total damage is estimated at USD 304 million, and in a 1000-year return period event the cost rises to USD 2.26 billion. The direct risk information was further analyzed using the Catastrophe Simulation (CATSIM) model, which indicates that Cambodia will likely face a fiscal resource gap-with disaster losses outpacing available funding for recoveryfollowing as frequent as a 28 -year return period event. Such a gap is estimated to rise as events become rarer but gain intensity, from USD 123 million for a 50-year return period event to USD 290 million for a 100-year return period event and to USD 533 million for a 500-year return period event. Reviews of Cambodian government regulations, together with interviews with national policymakers, reveal that fiscal preparedness against natural disasters is limited and that there are a number of barriers to effective risk management. To improve the country's preparedness against natural disaster risk, the authors recommend the following steps: (1) build an inventory of existing DRM expenditure to clarify the availability and use of fiscal resources; (2) collect and validate further risk information; (3) create institutional support for DRM; and (4) implement risk-based fiscal planning.

The remainder of the article is organized as follows: Sect. 2 discusses the general background of natural disaster risk and developmental challenges facing Cambodia. Section 3 explains the methodology and data used for direct and fiscal risk assessments. Section 4 explains the results of our analyses and Sect. 5 provides further discussion. Finally, Sect. 6 presents some major policy recommendations for effective DRM in Cambodia.

\section{Natural Disasters and Developmental Challenges in Cambodia}

Cambodia is located in Southeast Asia, north of the gulf of Thailand between Vietnam to the east, Laos to the northeast, and Thailand to the northwest and west. The country has a total land area of approximately $181,000 \mathrm{~km}^{2}$ of which $4500 \mathrm{~km}^{2}$ is composed of waterbodies (CIA 2014). Cambodia's exposure and vulnerability to natural 
Table 1 Largest Cambodian natural disasters in terms of numbers killed, affected, and economic damage from 1900 to 2014

\begin{tabular}{|c|c|c|c|c|c|c|}
\hline \multirow{2}{*}{$\begin{array}{l}\text { Rank } \\
1\end{array}$} & \multicolumn{2}{|c|}{ Numbers killed } & \multicolumn{2}{|c|}{ Numbers affected (1000) } & \multicolumn{2}{|c|}{$\begin{array}{l}\text { Total economic damage } \\
\text { (USD 1000) }\end{array}$} \\
\hline & 506 & Flood 1994 & 5000 & Drought 1994 & 521,000 & Flood 2011 \\
\hline 2 & 475 & Epidemic 1998 & 3448 & Flood 2000 & 160,000 & Flood 2000 \\
\hline 3 & 347 & Flood 2000 & 1669 & Flood 2001 & 150,000 & Flood 1991 \\
\hline 4 & 247 & Flood 2011 & 1640 & Flood 2011 & 100,000 & Drought 1994 \\
\hline 5 & 182 & Epidemic 2007 & 1470 & Flood 2002 & 70,000 & Flood 2010 \\
\hline 6 & 100 & Flood 1991 & 1300 & Flood 1996 & 38,000 & Drought 2002 \\
\hline 7 & 59 & Flood 1996 & 900 & Flood 1991 & 15,000 & Flood 2001 \\
\hline 8 & 56 & Epidemic 1999 & 650 & Drought 2002 & 1500 & Flood 1996 \\
\hline 9 & 56 & Flood 2001 & 600 & Drought 2005 & 1000 & Flood 2007 \\
\hline 10 & 50 & Epidemic 1992 & 536 & Flood 1999 & 500 & Flood 1999 \\
\hline
\end{tabular}

Source CRED (2014)

hazards-floods and droughts in particular-stem from its unique natural geographic and socioeconomic contexts. While the low-lying plains along the Mekong River and the Tonlé Sap lake and river system are highly exposed to flood hazards, a lack of irrigation infrastructure and variable weather also render the country susceptible to seasonal droughts. Provinces including Banteay Meanchey, Battambang, Siem Reap, Pursat, Kampong Chhnang, Kampong Thom, Kampong Cham, and Prey Veng are most frequently affected by flooding, while provinces such as Kandal, Prey Veng, and Svay Rieng are prone to drought (CHRF 2013; NCDM 2013). Table 1 shows the largest natural disaster events in terms of the numbers of people killed, population affected, and the cost of economic damage.

Catastrophic natural disaster is increasingly seen as an impediment to the country's socioeconomic development goals (Chhinh and Poch 2012; Vathana et al. 2012; Center of Excellence in Disaster Management and Humanitarian Assistance 2014). Despite the rapid economic growth achieved in recent years, poverty reduction remains an important development agenda in Cambodia, as the poverty headcount ratio (the proportion of people living below USD 2.00 per day) stands at $50 \%$ of the population as of 2009 (World Bank 2014). The achievements of socioeconomic development vary widely across the country-for example, the literacy rate in urban areas is above $90 \%$, but is below $50 \%$ in remote provinces (Cambodia National Institute of Statistics 2011). Access to improved sanitation is also only $25 \%$ in rural areas as opposed to above $80 \%$ achieved in urban areas (CIA 2014). There is still limited understanding regarding how natural disaster occurrences affect socioeconomic development over time in Cambodia, but existing evidence shows that the occurrence of drought was associated with a $6 \%$ increase in the poverty rate, while that of flood was associated with a poverty rate reduction of $4 \%$ nationwide (Kimsun and Bopharath
2011). ${ }^{1}$ The long-term implications of repeated disaster events could in fact be debilitating, as social safety nets (in the form of crop and property insurance, for example) are virtually nonexistent in Cambodia (Center of Excellence Disaster Management and Humanitarian Assistance 2014).

Although the national-level planning of development and poverty reduction formally recognizes the important link between development and disasters, many challenges remain in the substantive implementation of the country's DRM strategy. The country's key policy roadmaps including the National Poverty Reduction Strategy (NPRS) (Royal Government of Cambodia 2002) and the Strategic National Development Plan 2009-2013 (Royal Government of Cambodia 2009) both recognize the need for disaster management. The National Committee for Disaster Management (NCDM) was also established in 1995 as an inter-agency coordinating body for mitigation, preparedness, response, and recovery activities. However, Cambodia's disaster management institution has since faced chronic shortages of human and economic resources and the NCDM remains a response-oriented-rather than a proactive risk management-oriented—body without any standing budget (Nguyen et al. 2010).

The recent international aid allocation also reflects the response-oriented nature of the country's disaster management. From 1991 to 2014, Cambodia received USD 785.34 million in foreign aid for disaster management with $55 \%$ used for emergency response, $35 \%$ for reconstruction and rehabilitation, and $10 \%$ for disaster preparedness projects. The average project size, in terms of investment,

\footnotetext{
1 The positive association between floods and poverty is likely due to the fact that mild annual floods bring ecological and economic benefits including improved dry season paddy production and freshwater fish catches (Kimsun and Bopharath 2011). Damage and losses associated with catastrophic disasters, as opposed to smaller, more frequent events, often far outweigh the benefits of natural disasters.
} 
is USD 1.49 million for emergency response, USD 45.61 million for reconstruction and rehabilitation, and USD 3.81 million for disaster preparedness and prevention (AidData 2014). As will be analyzed below, response-oriented disaster management will likely pose an increasing challenge as continued urbanization and asset accumulation in hazard-prone areas may well increase the country's economic risk following natural disasters.

\section{Methodology and Data}

This study combines bottom-up probabilistic economic risk assessments and a fiscal resource analysis that uses the CATSIM approach explained below. We also conducted face-to-face interviews with national policymakers, together with a series of workshops with approximately 30 national, district, and commune-level officials where we validated our modeling assumptions and results (ADPC 2013; Mochizuki 2014). The interviews further elicited information regarding policymakers' knowledge and attitudes regarding DRM in Cambodia.

The economic risk due to typhoons (tropical depression and storms) and floods were estimated using the probabilistic risk assessment (CAPRA) model (http://www.ecapra.org/), which combines information on hazards, exposure, and vulnerability. For typhoons, past events affecting Cambodia and its neighbors were simulated using the Advance Research WRF (ARW) model developed by the National Centre for Atmospheric Research (NCAR) (http://www2. $\mathrm{mmm}$.ucar.edu/wrf/users/). Simulation outputs with wind speed at $10 \mathrm{~m}$ above the surface were extracted and used in the following analysis. For floods, historical rainfall data were analyzed using a Gumbel distribution. Rainfall return period data and recordings of discharge and water levels at local measurement stations were used as inputs to a hydrological model (HEC-HMS) (http://www.hec.usace.army. $\mathrm{mil} /$ software/hec-hms/). Discharges for different return periods were then converted to the water level at the outlet of the subbasins based on Manning's equation. The results were verified using historical flood records and Google Earth images.

Exposure information for private houses was gathered through commune-level statistics and the locations of government buildings (administrative buildings, hospitals, and schools) were gathered in collaboration with local government agencies. Because the exact location of houses was not available in Cambodia, this study assumed that houses were at the center of communes. Given the dearth of risk assessments conducted in Cambodia, this study adopted vulnerability curves from existing studies conducted in neighboring countries. The local buildings were categorized into semiengineered (SE) and nonengineered (NE) design houses based on their vulnerability to typhoon wind as analyzed in Goyal et al. (2012). Their study did not provide damage functions in monetary values, although the loss functions from HAZUS-MH (FEMA 2012) were utilized to derive economic values. The flood vulnerability functions were adopted from Sagala (2006). Individual risk curves used in estimations for typhoons and floods were combined using convolution. The detailed information regarding the bottomup risk assessment is available in NCDM (2014).

The information regarding direct risk and fiscal resources was analyzed using the CATSIM model. CATSIM is an integrated framework for ex ante (before-the-event) assessment of disaster risk in terms of public finance and economic growth impacts. The methodology integrates a catastrophic risk analysis with economic modules, and identifies the trade-offs and synergies between risk management investment and development (Fig. 1). In this study, a bottom-up direct risk assessment was conducted by collecting hazard, exposure, and vulnerability of public and private buildings against floods and cyclones in Step 1. Economic parameters and fiscal resources availability were gathered through desktop reviews and stakeholder workshops and interviews in Step 2. The outputs of these steps were then combined to estimate the concept of fiscal resources gaps in Step 3. Further, a dynamic inter-industry economic model was built to estimate indirect follow-on impacts in Step 4. The results of Step 3 and 4 were explained to national-level policymakers in an interactive workshop, in which participants evaluated different ex ante and ex post risk management policy options as Step 5. The model has been widely used to assess the fiscal and economic risks of natural disasters at various scales including individual country case studies (Mechler 2004; Birkmann 2007; Michel-Kerjan et al. 2013); regional studies (Hochrainer-Stigler et al. 2013); and global scale studies (Hochrainer-Stigler et al. 2014). For further details regarding modeling procedures, readers can refer to Mechler (2004) and Hochrainer-Stigler (2007, 2012).

For our analysis, the inventory of available fiscal resources was built using primary and secondary data gathered through interviews and desktop reviews. Currently, the Cambodian government relies solely on ex post financing options, with limited investment in disaster risk reduction (Table 2). To quantify the potential benefits of ex ante fiscal arrangements, the study further built the dynamic inoperability input-output (DIIM) model and simulated the indirect, interindustry effects of a hypothetical flood event in which transportation sector damage induces indirect losses in the wider economy. This is a hypothetical flood event in which key parameters, including the duration of inundation, extent of direct damage, and timing of reconstruction processes, are calibrated to the 2011 floods, based on the available literature (ADB 2012a; IRITWG 2012) and expert interviews (Ministry of Public Works and Transportation 2014). A 15 sector input-output table of the 
Fig. 1 CATSIM model steps. Source Hochrainer-Stigler (2012, p. 17). Reprint with permission of Springer

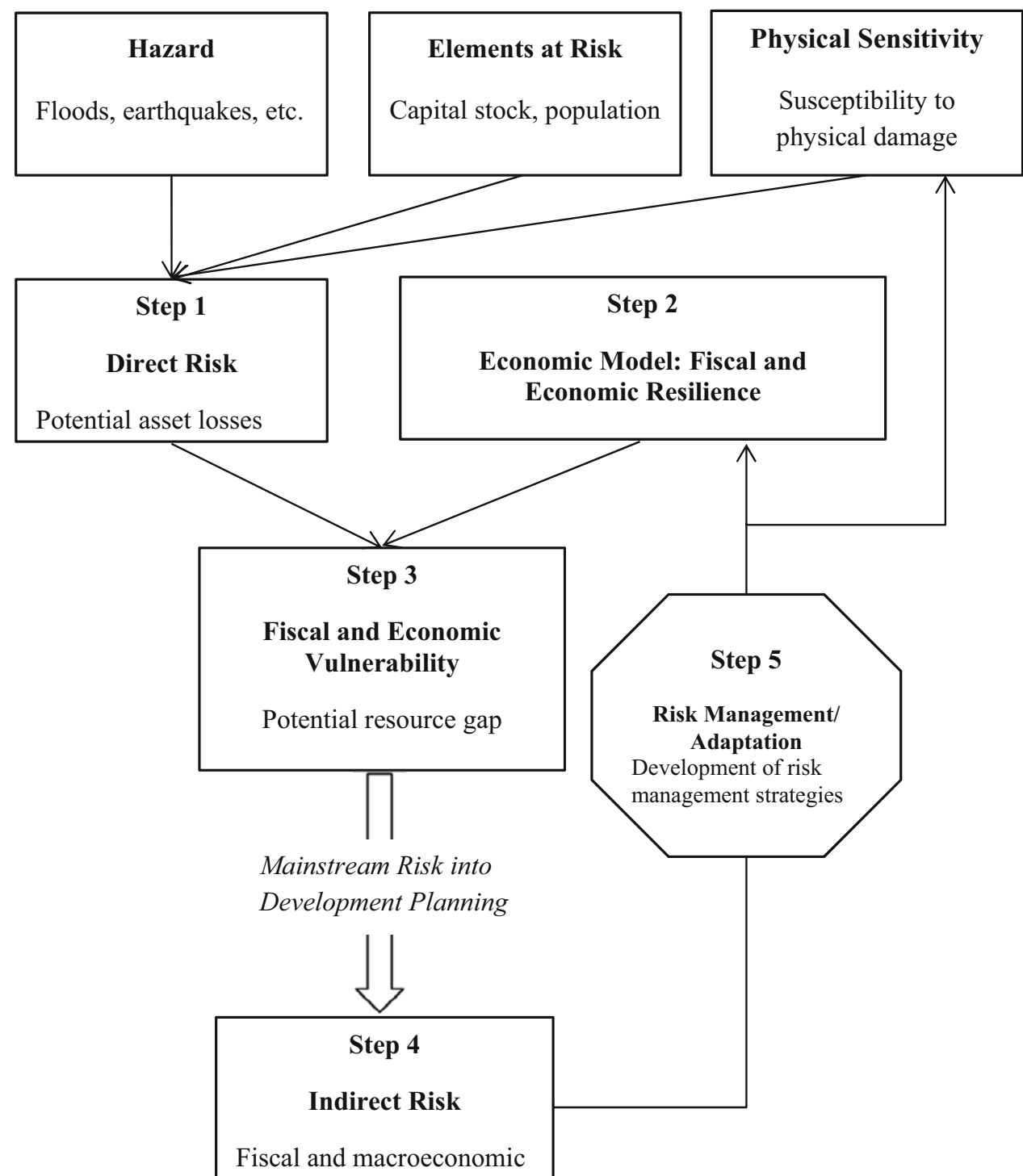

Cambodian economy with a benchmark year of 2005 was used (ADB 2012b).

In more detail, a static inoperability input-output (IIM) model can be expressed as follows based on Santos (2006):

$q=A^{*} q+c^{*}$

where $q$ is the vector of sector inoperability, $A^{*}$ is the interdependency matrix, and $c^{*}$ is the vector of demand perturbation. Sector inoperability is based on the traditional input coefficients normalized based on sector output. Given the large contribution of some sectors to imports in the Cambodian economy, normalization is performed using the concept of gross trade economy (GTE) incorporating the contribution of sector imports (Jung et al. 2009):

$$
\begin{aligned}
\mathrm{GTE}= & \mathrm{GDP}+M=\mathrm{DD}+X+M \\
= & (\text { Domestic products for domestic use })+(\text { exports }) \\
& +(\text { imports })
\end{aligned}
$$

Using the concept of GTE, the Leontief technical coefficients are normalized as follows:

$$
\begin{aligned}
A * & =\left[\left(\operatorname{diag}\left(\hat{x}^{T}\right)\right)^{-1}\right][A]\left[\left(\operatorname{diag}\left(\hat{x}^{T}\right)\right)\right] \\
& =\left[\begin{array}{ccc}
a_{1,1} \frac{x_{1}^{T}}{x_{1}^{T}} & \cdots & a_{1, n} \frac{x_{n}^{T}}{x_{1}^{T}} \\
\vdots & \ddots & \vdots \\
a_{n, 1} \frac{x_{1}^{T}}{x_{n}^{T}} & \cdots & a_{n, n} \frac{x_{n}^{T}}{x_{n}^{T}}
\end{array}\right]
\end{aligned}
$$


Table 2 Baseline assumptions used in CATSIM Fiscal Gap Analysis

Source

Ex post option

Contingency budget

Additional taxation

Domestic credit

MFI borrowing

International borrowing

International aid

Ex ante options

Reserve fund

Contingent credit agreement

Sovereign insurance

Liability assumption

The total capital stock is estimated at USD 69.1 billion

$30 \%$ of total expected losses is losses to public assets

$20 \%$ of total expected losses is used for private sector relief and recovery

USD 115 million $^{\mathrm{a}}$
Not applicable
Not applicable
USD 309 million $(200 \text { million SDR })^{\mathrm{b}}$
Not applicable
$10.4 \%$ of direct damage

Not applicable in the baseline

Not applicable in the baseline

Not applicable in the baseline
NGO Forum on Cambodia (2013)

World Bank (2012)

Ministry of Economy and Finance (2014)

JICA (2011)

Ministry interview

Freeman et al. (2002)

World Bank (2012)

World Bank (2012)

World Bank (2012)

University of Pennsylvania (2013)

Hochrainer-Stigler et al. (2014)

Hochrainer-Stigler et al. (2014)

a The annual average of unexpected expense over the past 5 years

b Assuming $50 \%$ of the Multilateral Financial Institution (MFI) borrowing limit can be used for disaster recovery and reconstruction

where $\hat{x}^{T}$ denotes the planned level of industry production expressed in terms of GTE. $A$ is the traditional Leontief technical confident matrix.

Based on Santos (2012), a static IIM model can then be extended dynamically as follows:

$q(t+1)=q(t)+K[A * q(t)+c *(t)-q(t)]$

where $K$ is referred to as an "industry resilience coefficient matrix," which determines how fast sectors can readjust in response to supply and demand imbalances (Lian and Haimes 2006). A diagonal element in the sector resilience coefficient matrix noted as $k_{i i}$ is estimated as:

$k_{i i}=\frac{\ln \left[q_{i}(o)-q_{i}\left(T_{i}\right)\right.}{T_{i}}\left(\frac{1}{1-a_{i i}^{*}}\right)$

where $q_{i}(o)$ is the initial inoperability of sector $i$ and $q_{i}(T)$ is the final level of inoperability at time $\mathrm{T}$. $\mathrm{T}$ denotes speed of recovery.

Without considering the potential of inventory contribution, the total economic loss in sector $i\left(\tilde{x}_{i}\right)$ in terms of GTE incurred due to the inoperability can be estimated as:

$\tilde{x}_{i}=\sum_{t} \sum_{i} q_{i t} * X_{i}$

where $X_{i}$ is the planned level of production in sector $i$.

The following two hypothetical policy scenarios are evaluated within the dynamic inoperability input-output (DIIM) framework. The baseline disaster damage scenario for both cases assumes that $30 \%$ of Cambodia's transportation sector becomes inundated (inoperable) for 30 days due to a 50-year return period flood event in which
$60 \%$ of the inundated roads become physically damaged (IRITWG 2012) and continue to be inoperable at the end of inundation period. In policy scenario 1 , the Cambodian government waits 6 months for the delivery of external funding assistance without ex ante arrangements (Ministry of Public Works and Transportation 2014). Therefore the reconstruction phrase begins at the beginning of month eight. In policy scenario 2 (with ex ante arrangement), the reconstruction phase may begin almost immediately after the inundation period. In both scenarios, the reconstruction phase is assumed to take 11 months.

\section{Results}

The following sectors describe the results of probabilistic risk assessment, followed by economic and fiscal risk analysis in Cambodia.

\subsection{Bottom-up Direct Risk Assessment}

Hazard, exposure, and vulnerability assessments highlight considerable disaster risk facing Cambodia due to floods and typhoons. Of 2.8 million houses documented in the commune statistics, approximately $55 \%$ were found to be located in potentially flooded areas. Almost $30 \%$ of total housing stock is exposed to flood levels above $2 \mathrm{~m}$. Wood and metal structures are the most common housing materials constituting approximately $80-90 \%$ of building materials used. Concrete structures account for approximately $7 \%$ of the total housing stock in nonflooding areas, 
while $10 \%$ are located in areas with potential flooding of less than $2 \mathrm{~m}$ and $20 \%$ are found in areas with potential flooding above $2 \mathrm{~m}$. As for storm and typhoon risks, $63 \%$ of the total housing stock in the country was found to be in areas exposed to tropical depressions with a wind speed of less than $61 \mathrm{~km} / \mathrm{h}$, and $37 \%$ were found within the areas exposed to tropical storms between 62 and $88 \mathrm{~km} / \mathrm{h}$ in wind speed. Exposure to typhoons (above $118 \mathrm{~km} / \mathrm{h}$ in wind speed) was found to be low, with less than $1 \%$ of houses located in hazardous zones.

Of 1850, commune, district, and province centers nationwide, $60 \%$ were found to be located in nonflooding areas, whereas $10 \%$ were located in areas with potential flooding of less than $2 \mathrm{~m}$, and $30 \%$ located in areas with potential flooding of more than $2 \mathrm{~m}$. As for storm and typhoon risks, $64 \%$ of administrative centers were found to be in the areas exposed to tropical depressions with a wind speed of less than $61 \mathrm{~km} / \mathrm{h}$, and $35 \%$ were within the areas exposed to tropical storms of between 62 and $88 \mathrm{~km} /$ $\mathrm{h}$ in wind-speed.

Health and educational facilities are also highly exposed. Of 1019 health facilities established in the country, $55 \%$ were found to be in nonflooding areas, while $12 \%$ were found to be in areas with potential flooding of less than $2 \mathrm{~m}$, and $33 \%$ were located in areas with potential flooding of above $2 \mathrm{~m}$. Of 6929 educational facilities available nationwide, $62 \%$ were situated in nonflooding sites, while $10 \%$ were found in areas with less than $2 \mathrm{~m}$ floods and the remainder occupied areas with more than $2 \mathrm{~m}$ floods. For storm and typhoon risks, $64 \%$ of health and $69 \%$ of educational facilities were constructed in areas exposed to tropical depression with a wind speed of less than $61 \mathrm{~km} / \mathrm{h} ; 36 \%$ of health and $31 \%$ of educational facilities were positioned within areas exposed to tropical storms of between 62 and $88 \mathrm{~km} / \mathrm{h}$ in wind speed.

The relationships between disaster risk and development status of different provinces do not seem straightforward. Provinces such as Phnom Penh and Kandal have achieved considerable reduction in poverty despite flood and storm exposure remaining high (Table 3). The lack of historical analysis of exposure does not permit detailed assessment. But it is plausible that more assets have been built in hazard-prone areas of these provinces over the past years and this explains the high exposure in these areas. On the other hand, provinces such as Kampong Thom, Kampong Chhnang, and Siem Reap face both high rates of poverty and high exposure to floods and, to a lesser extent, storms. These are the provinces where repeated disaster damage and losses may well constrain the prospects for poverty reduction. The duality of Cambodia's disaster and development challenges is clear. Continued urbanization and asset accumulation in hazard-prone areas will likely increase the economic costs of natural disasters. Increased economic costs will likely burden the country's limited budget for the foreseeable future. At the same time, repeated natural disaster damage and losses pose significant burdens for the poor and vulnerable populations in remote provinces.

Based on the bottom-up assessment, the annual average loss (AAL) due to floods is estimated at USD 95.9 million (housing), USD 0.347 million(commune centers), USD 0.0047 million (district centers), USD 0.0193 million (province centers), USD 6.5 million (educational facilities), and USD 0.370 million (health facilities). The AAL for storm and typhoon hazards is estimated to be USD 24.03 million (housing), USD 0.00145 million (commune centers), USD 0.000612 million (district centers), USD

Table 3 Top 10 provinces in terms of housing exposure to above $2 \mathrm{~m}$ flood and other variables

\begin{tabular}{lllll}
\hline & $\begin{array}{l}\text { Poverty } \\
\text { Headcount ratio (\%) }\end{array}$ & $\begin{array}{l}\text { Flood height } \\
0-2 \mathrm{~m}(\%)\end{array}$ & $\begin{array}{l}\text { Flood height } \\
>2 \mathrm{~m}(\%)\end{array}$ & $\begin{array}{l}\text { Storm wind speed } \\
62-118 \mathrm{~km} / \mathrm{h}(\%)\end{array}$ \\
\hline Phnom Penh & 11 & 6 & 88 & 71 \\
Kandal & 16 & 3 & 82 & 51 \\
Prey Veng & 20 & 9 & 65 & 69 \\
Kampong Thom & 30 & 12 & 46 & 1 \\
Kampong Cham & 21 & 11 & 39 & 17 \\
Kampong Chhnang & 28 & 10 & 32 & 13 \\
Siemreap & 31 & 17 & 28 & 4 \\
Pursat & 29 & 13 & 24 & 20 \\
Takeo & 19 & 18 & 24 & 79 \\
Banteay Meanchey & 26 & 9 & 20 & 11 \\
\hline
\end{tabular}

Source Poverty data compiled from Royal Government of Cambodia and WFP (2013); flood and cyclone risk estimates are from the authors' own calculation 


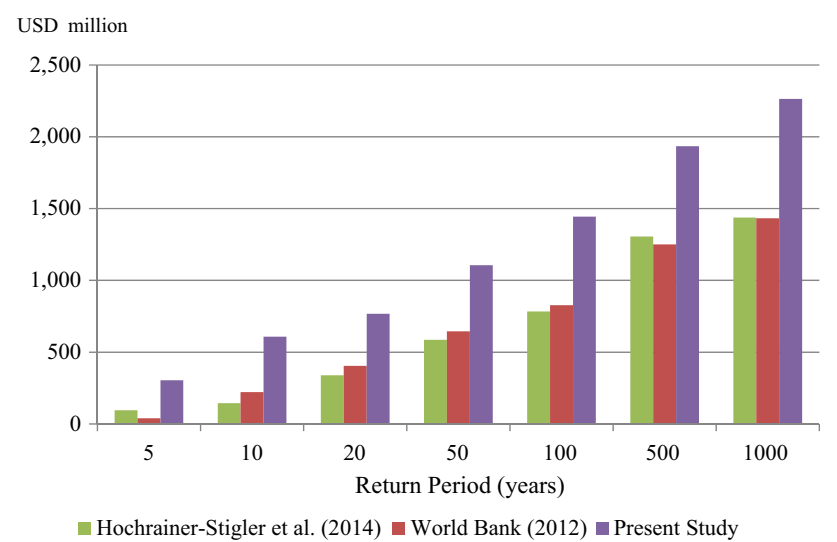

Fig. 2 Estimated direct economic risk and return periods due to natural hazards. Source Hochrainer-Stigler et al. (2014); World Bank (2012) ${ }^{\dagger}$; compiled by the authors. Note ${ }^{\dagger}$ The study reported expected losses for 20-, 100-, and 200-year return period events only; thus, the remaining data points have been interpolated

0.000339 million (province centers), USD 0.0189 million (educational facilities), and USD 0.000677 million (health facilities). Figure 2 shows an aggregated bottom-up economic risk estimate in comparison with top-down estimates available in existing studies. As shown, the current study shows higher aggregate economic risk even though this study only included risks due to two hazards and the values of key infrastructure such as transportation are not included. In the cases of 100-year and 500-year return period events, for example, the present estimates are approximately $75-83 \%$ and $48-55 \%$ higher than previously estimated. This may be due to the fact that existing datasets of disaster damage and losses for Cambodia, including the EM-DAT dataset, often used in top-down estimates, are incomplete and the costs associated with small and frequently occurring disasters such as floods have been overlooked in these databases.

\subsection{Fiscal Risk Assessment Results}

Literature reviews and local interviews indicate that Cambodia currently relies solely on ex post sources to finance recovery and reconstruction. Budget diversion and Multilateral Financial Institution (MFI) borrowing are the major sources of funds given the country's limited ability to raise taxes and to access domestic and international credit in the case of a disaster. Though domestic bonds have been issued to a limited extent in Cambodia (for example, USD 4 million was issued in the early 2000s) (IMF 2012), this is largely regarded as an unviable option for resource mobilization in the immediate future. For budget diversion, the Cambodian government has a limited amount of unallocated funds in the budget that can be used ex post to fund unforeseen needs. As specified in Articles
22-25 of the country's law on public finance (NGO Forum on Cambodia 2008), Cambodia's current expenditure is divided into: (1) real expenditures; and (2) expenditures by order and unexpected expenditures. Unexpected expenditures "cover any expense whose allocation cannot be accurately specified when credit is approved" (NGO Forum on Cambodia 2008, p. 8). The uses of this unexpected expenditure include nondisaster purposes such as election expenditures and interest payments; to what extent unallocated budget resources can be used for recovery and reconstruction purposes remains unknown. For external borrowing, there is an upper limit of USD 617 million (400 million special drawing rights, SDR), as agreed with the International Monetary Fund (JICA 2011).

Combining the information regarding fiscal resources and the probabilistic estimates of recovery and reconstruction funding needs, it is estimated that Cambodia will likely face a fiscal resource gap following a 28 -year return period event. Fiscal resource gaps are estimated to rise to USD 123 million following a 50-year return period event, USD 290 million following a 100-year return period event, and USD 533 million following a 500-year return period event (Fig. 3). The MFI borrowing constitutes the largest portion of reconstruction funding contributions in all cases, which could pose significant opportunity costs in terms of resources diverted from other developmental projects. Cambodia is expected to become a lower to middle-income country in the near future and will face stricter lending terms. The reliance on ex post financing could also cost more in terms of delayed recovery and reconstruction, as disbursement of post-disaster emergency lending typically takes around 6 months (Ministry of Economy and Finance 2014).

As for the breakdown of capital needs, it is estimated that the recovery and reconstruction needs of school buildings account for $15 \%$ (20-year return period) to $13 \%$ (500-year return period) of the total expense, while the needs of other public buildings have a smaller share of below $1 \%$ (Fig. 4). The contribution of public building reconstruction is minimal, because much of the economic damage is expected to occur with private houses in the present bottom-up estimate. The lack of detailed risk assessment regarding key infrastructure, such as transportation, bridges, irrigation infrastructure, and water supplies, together with other assets such as the value of agricultural crops, private business facilities, and so on, only permit crude assessment currently. The present study gives higher direct damage estimations despite these missing analyses, indicating the need for further risk assessment and better fiscal preparedness in Cambodia. The present risk assessment does not take the economic costs of indirect losses nor intangible damage and losses into account. 
Fig. 3 Post-disaster funding sources and resources gap. Source The authors
USD million

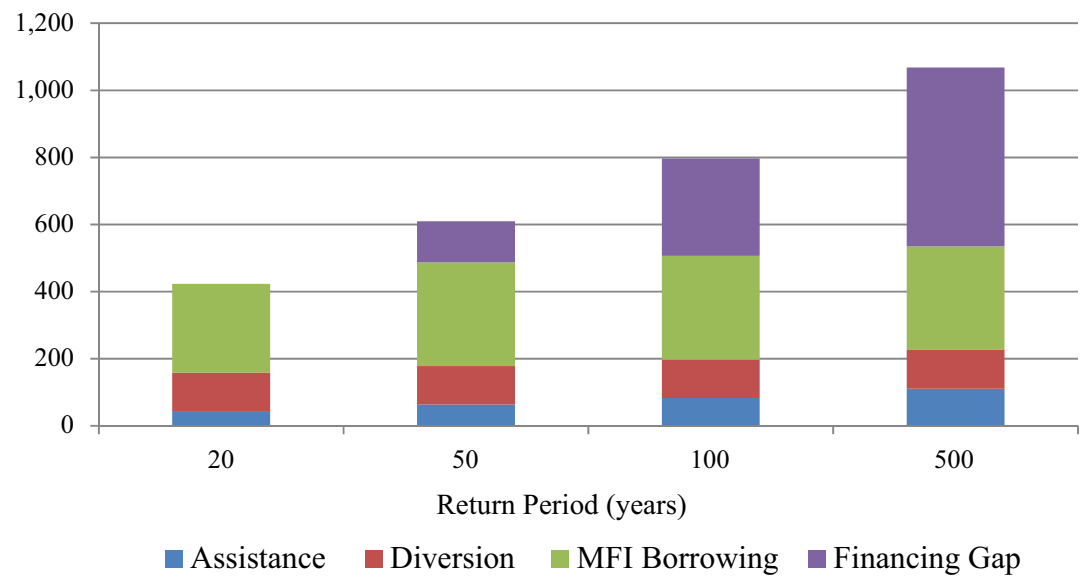

USD million

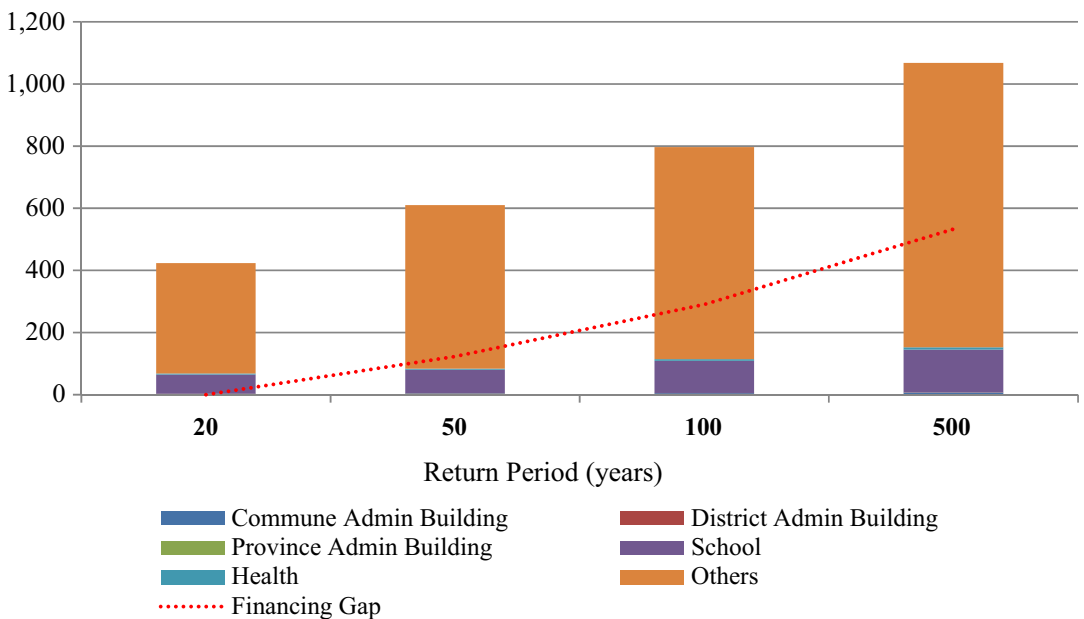

Fig. 4 Break-down on postdisaster recovery and reconstruction needs. Source The authors
The government's liabilities are sizable as compared to the overall size of Cambodia's government revenue. In the case of a 100-year return period event, the total capital need for recovery and reconstruction is estimated to account for as much as $38 \%$ of domestic revenue (excluding external borrowing) and $50 \%$ of domestic revenue in the case of a 500-year return period event. It is important to note that the present analysis assumes that $50 \%$ of the total economic losses will be financed by households and private businesses, which could have significant macroeconomic and developmental implications in terms of reduced consumption and savings in the long term. Given the lack of private insurance and other social safety nets to support these private losses, natural disasters could pose significant threats, especially to lower-income households and small businesses.

A dynamic fiscal model analysis shows that over the next 5 years, the likelihood that the Cambodian government will face a fiscal resource gap is estimated to be approximately $50 \%$. This relatively high probability is due to the fact that disaster occurrence is frequent in Cambodia, and the cumulative effect of frequent disaster events will likely stress the fiscal situation. Based on the risk layering framework (Hochrainer-Stigler and Pflug 2012; Mechler et al. 2014), it can be inferred that investment in risk reduction would be the most effective way to manage disaster risk, as a fiscal resource gap is estimated to be relatively low, following a 28 -year return period event. In addition, investment in a reserve fund as opposed to costlier alternatives such as sovereign insurance and contingent credit agreements could be an effective option for Cambodia. By investing approximately USD 100 million in a reserve fund, it is estimated that the Cambodian government can reduce the risk of a fiscal gap to approximately $30 \%$. Assuming the cost effectiveness of risk reduction to be 4.5 (that is, for each USD 1 spent on mitigation, USD 4.5 can be saved) (Hochrainer-Stigler 2012), the probability of a resource gap will be reduced to $35 \%$ when USD 
100 million is invested in risk reduction activities. Over the next 10 years, the probability of a resource gap is estimated at approximately $90 \%$, but USD 100 million invested annually in mitigation will reduce this to $36 \%$ while the establishment of a reserve fund will reduce it to $45 \%$. As these examples show, risk reduction will increasingly become the most effective way to manage fiscal risk in the longer-term as more assets are built to support economic growth in Cambodia.

Natural disasters are known to cause a number of indirect or higher-order effects across sectors (Rose 2004; Hallegatte 2014), although limited data only permit general and illustrative analysis of this topic in Cambodia. To shed some light on this issue, we used the dynamic inoperability input output (DIIO) framework to quantify the time-dependent nature of indirect effects (Fig. 5). Under policy scenario 1 (ex ante financing), the total economic lossincluding the declines in final demand and intermediate demand-is estimated to be approximately USD 65 million, of which transport sector losses account for USD 31 million. Under policy scenario 2 (ex post financing), the total losses are estimated at USD 95 million, with transport sector losses accounting for a decline of USD 45.7 million. A lack of information regarding the detailed relationship between transport infrastructure damage and post-disaster transport demand does not permit accurate analysis. Nonetheless the benefit of financial and economic preparedness in averting business losses in time of disasters is clear. Any preparedness measures, including ex ante financial arrangement and other predisaster planning, can avert unnecessary losses and lead to a more resilient Cambodian economy in the longer-term.

Given the limited availability of data, results have to be treated with caution and may only serve an illustrative purpose. This modeling exercise also identified a number of knowledge gaps that must be filled to improve the quality of assessment, including (1) better tracking of reconstruction decisions and fund allocations made across a number of institutions, together with better tracking of reconstruction progress; (2) further information regarding transport demands at different locations; and (3) further assessment regarding transport infrastructure risk due to flooding. These lessons were communicated through a series of workshops and ministry visits.

\section{Discussion}

Fiscal preparedness against natural disasters and risk-sensitive public investment planning are increasingly seen as important aspects of development in hazard-prone countries such as Cambodia. Despite the relatively frequent occurrence of natural disasters in the country, the use of risk information is still limited. For example, local interviews revealed that risk is not considered in probabilistic terms in planning and construction of rural roads; the country is merely divided into two zones of flooded or nonflooded areas based on past experience of flood occurrence (Ministry of Rural Works 2014). The availability and use of basic information such as hazard risk maps are also
Fig. 5 Declines in economic output due to transport sector inoperability (in million USD). Source The authors' calculation based on 2005 input-output table (ADB 2012b)

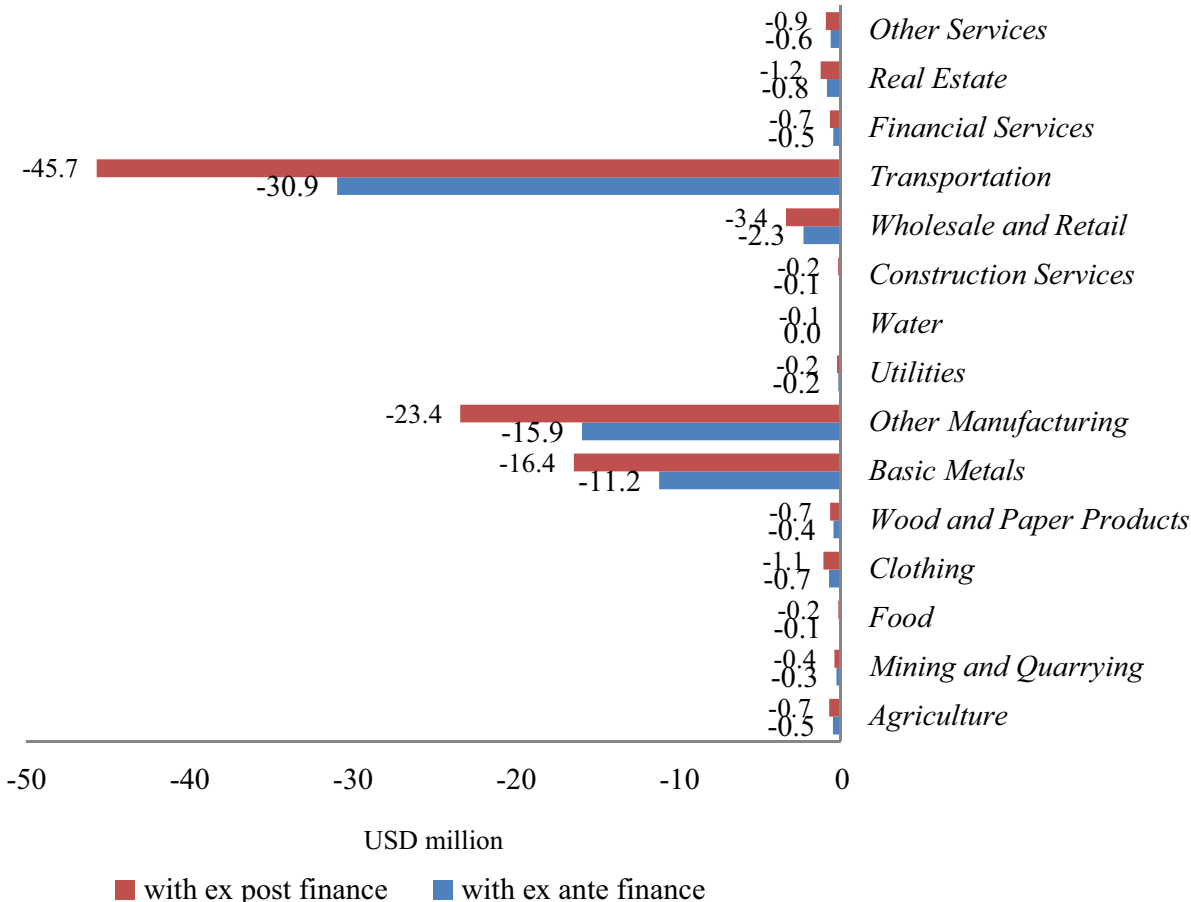

with ex post finance with ex ante finance 
nonexistent in major infrastructure planning such as national roads (Ministry of Public Works and Transportation 2014).Year after year, scarce resources have been wasted because they do not take disaster risk into account and infrastructure and development projects are halted or hampered due to the occurrence of natural disasters.

The present study highlighted some of the important insights regarding natural disaster risk management in Cambodia. The analysis indicated that Cambodia has a high probability of facing a fiscal resource gap in the near future, estimated at approximately $50 \%$ over the next 5 years and $90 \%$ over the next 10 years. Compared to its neighboring countries, Cambodia's fiscal preparedness is limited due to a number of factors, which include a lack of experience with catastrophic disaster events in the recent past and limited priority given to disaster risk reduction investment. Cambodia is estimated to face a resource gap following a 28 -year return period event, a more immediate prospect than the neighboring countries of Vietnam, the Philippines, and Malaysia that face similar gaps in terms of a 157-, 109-, and 116-year return period events respectively (Hochrainer-Stigler et al. 2014). At the same time, dynamic analysis highlighted the effectiveness of disaster risk reduction (DRR) investment in the longer term. As more economic assets are utilized in the country to spur economic growth, risk reduction will become an increasingly effective risk management tool in the future.

Therefore response-oriented fiscal planning and implementation are key concerns for Cambodia. Interviews with local policymakers revealed that understanding of future disaster risk as opposed to past damage and losses is still limited. National-level policymakers, for example, can recall the costs related to damage and losses of recent disaster events. But risk-related ideas such as return periods of disaster events and potential likelihood of catastrophic disaster events remain largely unfamiliar concepts. Local policymakers tend to rely on past disaster records as a benchmark for future disaster management planning, despite this practice being problematic for developing countries such as Cambodia, where past records only date back a few decades and rapid changes in the socioeconomic environment are taking place. Many policymakers view recent disaster events, such as the flood of 2011, as a catastrophic event when proper risk-based knowledge predicts that this flood event is estimated to occur "once every 10-20 years" (MRC 2011, p. 2). Therefore, forwardlooking risk assessment will help frame their mindset from the existing "event-focused" to future "risk-focused" framework in Cambodia.

Although national-level decision makers are generally aware of the fiscal issues related to disaster expenditures, such awareness has not translated into concrete DRM actions. For example, the disaster-proof infrastructure options promoted by donor agencies are seen as too expensive and impractical for Cambodia, even though local policymakers recognize that such options will in theory reduce risk and save their budget in the longer term (Ministry of Rural Works 2014). To reduce economic vulnerability over time, efforts must be made to remove these cognitive, economic, and institutional barriers. To improve risk assessment and risk management implementation within the iterative risk management framework, further efforts should be devoted to several important issues:

(1) Build an inventory of existing DRM expenditures and clarify fiscal resource availability. At present, disaster response, recovery, and reconstruction expenditures are approved on an ad hoc basis and no complete inventory exists on DRM expenditures across different ministries. Budget items such as "unexpected expenditure" have no clear allocation rules, and their availability in the case of a natural disaster remains ambiguous. Clarifying budget categories and understanding how budget expenditures are diverted each year due to natural disaster is an important first step in improving fiscal preparedness and addressing the opportunity costs associated with response-oriented fiscal planning.

(2) Improve data collection and risk assessment. Accurate and timely collection of disaster damage and loss data forms the foundation for evidence-based decision making and evaluation. The present article suggests that there is a considerable level of uncertainty about existing natural disaster risk in Cambodia. A number of donor-led initiatives have been implemented to improve the capacity of disaster damage and loss data collection in Cambodia (NCDM 2013); further effort is needed to validate risk information and to train policymakers in the use of that risk information.

(3) Create institutional support for effective DRM. Many decisions about capital investments are made within each ministry, but ministerial roles and responsibilities in disaster risk reduction and management need clarification. There have been occasions when investment in risk reduction was rejected because risk reduction was not integrated into the development goals of the country (Ministry of Public Works and Transportation 2014). The rapid rate of development taking place in Cambodia requires the integration of risk management into development plans to facilitate prospective risk reduction in the future.

(4) Evaluate the benefit of risk-based planning and prioritize risk management options based on a risklayering approach. Policymakers in general understand the need for disaster risk reduction, but the 
economic and social benefits of DRM investment (risk mitigation, risk transfer arrangements, and so on) are not widely recognized. Further studies are needed to quantify the benefits of DRM investment opportunities, and to identify affordable, easily implemented, low-regret DRM measures.

\section{Conclusion}

The Cambodian experience of DRM illustrates a number of common challenges faced by developing countries that wish to implement iterative risk management. Although the effectiveness of iterative risk management is viewed with "high confidence and robustness" globally, a useful first step in supporting its progress in developing countries is to clarify the on-the-ground reality that shapes the context for disaster risk management. One of the key issues identified in this article is the general lack of risk-based thinking, which reflects the lack of DRM mainstreaming in Cambodia. The notion of risk, or the potential for future harm, remains largely unfamiliar to many who makes important day-to-day decisions on Cambodia's development trajectories, including public infrastructure development and other social and economic programs. How to communicate risk-based languages to a nontechnical audience and assist them to adopt risk-based planning and budget allocation despite limited data availability are therefore important areas for further study.

This study also identified the existing lack of coordination in data gathering and sharing. This not only pertains to disaster damage and loss data, which is collected by the NCDM, but also other relevant current information on DRM-related expenditure and past information on disaster response and recovery. There are no clear statistics, for example, that enumerate what resources are wasted each year because of insufficient planning for annual floods. Yet keeping such an inventory and clearly communicating costs may provide a strong incentive to adopt risk-based planning. Overall, there is a need for improved collection and sharing of data and information, both to avoid duplication of effort and to ensure that learning achieved on one occasion leads to the next phase of action and learning in the iterative risk management cycle.

The availability of data and information, together with an ability to interpret their meaning, are important building blocks of iterative risk management. There is a further need to link risk-based insights to actionable decisions. For example, the macrolevel fiscal risk analysis provided in this study is useful to officials making national-level decisions about budget allocation. Individual ministries, in making their capital investment decisions, may need different assessment and communication strategies. To mainstream risk-based decision making, further work is needed to identify ways to tailor risk information to a particular decision setting. Only in this way is it possible to overcome existing cognitive, institutional, and economic barriers and to better link with tangible decision making and DRM implementation.

Open Access This article is distributed under the terms of the Creative Commons Attribution 4.0 International License (http://crea tivecommons.org/licenses/by/4.0/), which permits unrestricted use, distribution, and reproduction in any medium, provided you give appropriate credit to the original author(s) and the source, provide a link to the Creative Commons license, and indicate if changes were made.

\section{References}

ADB (Asian Development Bank). 2012a. Briefing notes on Cambodia 2011 floods and ADB responses. http://www.adb.org/sites/default/ files/briefing-notes-5sep2012.pdf. Accessed 10 May 2014.

ADB (Asian Development Bank). 2012b. Supply and use tables for selected economies in Asia and the Pacific: A research study. http://www.adb.org/publications/supply-and-use-tables-selectedeconomies-asia-and-pacific-research-study. Accessed 10 May 2014.

ADPC (Asian Disaster Preparedness Center). 2013. Workshop discusses gaps in risk assessment, early warning system and procedures for developing building codes. http://www.adpc.net/2012/gateway. asp?DocID=373. Accessed 10 Jan 2014.

AidData. 2014. Disaster aid tracking. http://gfdrr.aiddata.org/dash board/dashboard?showDisclaimer=false. Accessed 10 May 2014.

AMCDRR (Asian Ministerial Conference on Disaster Risk Reduction). 2014. Promoting investments for resilient nations and communities. http://6thamcdrr-thailand.net/6thamcdrr/Portals/0/ FINAL-6\%20AMC\%20Consolidated $\% 20$ background $\% 20$ docu ment $\% 20$ version $\% 2009 \% 20 J u n e-c l e a n-f o r \% 20$ design-sent $\% 20$ to\%20DDPM-12\%20june\%20.pdf. Accessed 10 May 2014.

American Red Cross. 2013. Local disaster risk reduction and management fund. http://preparecenter.org/resources/examples/ Local\%20Disaster\%20Risk\%20Reduction\%20and\%20Manage ment\%20Fund\%20\%28LDRRMF\%29. Accessed 10 May 2014.

Bettencourt, S., R. Croad, P. Freeman, J. Hay, R. Jones, P. King, P. Lal, A. Mearns et al. 2006. Not if, but when: Adapting to natural hazards in the Pacific Islands region. A policy note. Washington, DC: World Bank. http://siteresources.worldbank.org/INTPACI FICISLANDS/Resources/Natural-Hazards-report.pdf. Accessed 10 Sept 2014.

Birkmann, J. (ed.). 2007. Measuring vulnerability to natural hazards: Towards disaster resilient societies. New Delhi: TERI Press.

Cambodia National Institute of Statistics. 2011. The Cambodian statistical yearbook 2011 edition. Phnom Penh: National Institute of Statistics, Ministry of Planning.

Center of Excellence in Disaster Management and Humanitarian Assistance. 2014. Disaster management reference handbookCambodia. http://reliefweb.int/report/cambodia/disaster-manage ment-reference-handbook-cambodia. Accessed 10 May 2014.

Chhinh, N., and B. Poch. 2012. Climate change impacts on agriculture and vulnerability as expected poverty of Kampong Speu Province, Cambodia. International Journal of Environmental and Rural Development 3(2): 28-37. 
CHRF (Cambodia Humanitarian Response Forum). 2013. Cambodia: Floods. http://reliefweb.int/report/cambodia/floods-humanitarianresponse-forum-hrf-final-report-no-07-07-december-2013. Accessed 10 May 2014.

CIA (Central Intelligence Agency). 2014. The world factbook. Cambodia. https://www.cia.gov/library/publications/the-worldfactbook/geos/cb.html. Accessed 10 May 2014.

CRED (Centre for Research on the Epidemiology of Disasters). 2014. EM-DAT, The International Disaster Database. http://www. emdat.be/country_profile/index.html. Accessed 10 May 2014.

FEMA (Federal Emergency Management Agency). 2012. Multiplehazard loss estimation methodology: Hurricane model HazusMH 2.1 technical manual. http://www.fema.gov/media-librarydata/20130726-1820-25045-8522/hzmh2_1_hr_um.pdf. Accessed 10 May 2014.

Freeman, P.K., L. Martin, R. Mechler, K. Warner, and P. Hausmann. 2002. Catastrophes and development. Integrating natural catastrophes into development planning. Working Paper 26279. Washington, DC: World Bank.

GFDRR (Global Facility for Disaster Reduction and Recovery). 2013. FONDEN: Mexico's National Disaster Fund. https://www.gfdrr. org/sites/gfdrr.org/files/documents/Mexico_FONDEN_final_GFD RR.pdf. Accessed 10 May 2014.

Goyal, P.K., T.K. Datta, and V.K. Vijay. 2012. Vulnerability of rural houses to cyclonic wind. International Journal of Disaster Resilience in the Built Environment 3(1): 20-41.

Hallegatte, S. 2014. Natural disasters and climate change: An economic perspective. New York: Springer.

Hochrainer-Stigler, S. 2007. Macroeconomic risk management against natural disasters: Analysis focused on governments in developing countries. Berlin: Springer.

Hochrainer-Stigler, S. 2012. Financial and economic disaster risk estimation in Madgascar for the implementation of CatSim. Summary report. http://www.iiasa.ac.at/publication/more_XO12-034.php. Accessed 10 May 2014.

Hochrainer-Stigler, S., and G. Pflug. 2012. Risk management against extremes in a changing environment: A risk-layer approach using Copulas. Environmetrics 23(8): 663-672.

Hochrainer-Stigler, S, A. Timonina, K. Williges, G. Pflug, and R. Mechler. 2013. Modelling the economic and fiscal risks from natural disasters. Insights based on the CatSim model. http://www. preventionweb.net/english/hyogo/gar/2013/en/bgdocs/Hochrainer \%20et\%20al.\%202013.pdf. Accessed 10 Jun 2014.

Hochrainer-Stigler, S., R. Mechler, G. Pflug, and K. Williges. 2014. Funding public adaptation to climate-related disasters. Estimates for a global fund. Global Environmental Change 25: 87-96.

IMF (International Monetary Fund). 2012. Staff report for the 2012 Article IV consultation: Debt sustainability analysis. http://www. imf.org/external/pubs/ft/dsa/pdf/2013/dsacr1302.pdf. Accessed 10 June 2014.

IPCC (Intergovernmental Panel on Climate Change). 2007. IPCC fourth assessment report: Climate change 2007. Working group III: Mitigation of climate change. http://www.ipcc.ch/publica tions_and_data/ar4/wg3/en/contents.html. Accessed $10 \mathrm{Sept}$ 2014.

IPCC (Intergovernmental Panel on Climate Change). 2012. Special report on managing the risks of extreme events and disasters to advance climate change adaptation (SREX). http://ipcc-wg2. gov/SREX/report/. Accessed 10 June 2014.

IRITWG (Infrastructure and Regional Integration Technical Working Group). 2012. Overview on transport infrastructure sectors in the Kingdom of Cambodia, 4th edn. http://spied.mpwt.gov.kh/ pdf/Overview-on-Transport-Infrastructure-Sectors-in-Cambodia2012.pdf. Accessed 19 Sept 2015.

JICA (Japan International Cooperation Agency). 2011. In Cambodia, JICA conducts a debt sustainability analysis. JICA USA
November/December 2011. http://www.jica.go.jp/usa/english/ office/others/newsletter/2011/1111_12_05.html. Accessed 10 Jan 2014.

Jung, J., J.R. Santos, and Y.Y. Haimes. 2009. International trade inoperability input-output model (IT-IIM): Theory and application. Risk Analysis 29(1): 137-154.

Kimsun, T., and S. Bopharath. 2011. Poverty and environment links: The case of rural Cambodia. CDRI working paper series No. 64. http://www.cdri.org.kh/webdata/download/wp/wp64e.pdf. Accessed 10 May 2014.

Lian, C., and Y.Y. Haimes. 2006. Managing the risk of terrorism to interdependent infrastructure systems through the dynamic inoperability input-outupt model. Systems Engineering 9(3): 241-258.

Mechler, R. 2004. Natural disaster risk management and financing disaster losses in developing countries, vol. 1. Verlag Versicherungswirtsch. http://books.google.at/books?hl=en\&lr=\&id= onaqFvzPKzoC\&oi=fnd \&pg=PR13\&dq=mechler $+2004+$ disas ter\&ots=KhSP3ODIcw\&sig=y_HahfoN69IwDY_LasgyhkI_XRs. Accessed 10 May 2014.

Mechler, R., L.M. Bouwer, J. Linnerooth-Bayer, S. HochrainerStigler, J.C.J.H Aerts, S. Surminski, and K. Williges. 2014. Managing unnatural disaster risk from climate extremes. Nature Climate Change 4(4): 235-237.

Michel-Kerjan, E., S. Hochrainer-Stigler, H. Kunreuther, J. Linnerooth-Bayer, R. Mechler, R. Muir-Wood, N. Ranger, P. Vaziri, and M. Young. 2013. Catastrophe risk models for evaluating disaster risk reduction investments in developing countries. Risk Analysis 33(6): 984-999.

Ministry of Economy and Finance. 2014. Interview with local officials. June 2014.

Ministry of Public Works and Transportation. 2014. Interview with local officials. June 2014.

Ministry of Rural Works. 2014. Interview with local officials. June 2014.

Mochizuki, J. 2014. Risk-based planning in developing countriesCATSIM training in Cambodia. Nexus. 17 June 2014. The International Institute for Applied Systems Analysis (IIASA). http://blog.iiasa.ac.at/2014/06/17/toward-risk-based-planning-indeveloping-countries-catsim-training-in-cambodia/. Accessed 10 June 2014.

MRC (Mekong River Commission). 2011. Flood situation report 2011. MRC technical paper No.36. http://www.mrcmekong.org/ assets/Publications/technical/Tech-No36-Flood-Situation-Report 2011.pdf. Accessed 10 June 2014.

NCDM (National Committee for Disaster Management). 2013. DesInventar-Cambodia disaster loss and damage database (CamDi). http://camdi.ncdm.gov.kh/DesInventar/profiletab. jsp?countrycode $=\mathrm{kh} 855 \&$ maxhits $=25$. Accessed 10 Jun 2014.

NCDM (National Committee for Disaster Management). 2014. National and provincial risk assessment, Cambodia 2014. Phnom Penh: NCDM.

NGO Forum on Cambodia. 2008. Law on public finance system (unofficial translation). http://www.cambodianbudget.org/law_ on_public.php. Accessed 10 Jun 2014.

NGO Forum on Cambodia. 2013. Budget law database 2000-2013. http://www.cambodianbudget.org/budget_database.php. Accessed 10 June 2014.

Nguyen, H., R. Shaw, and S. Prabhakar. 2010. Climate change adaptation and disaster risk reduction in Cambodia. In Climate change adaptation and disaster risk reduction: An Asian perspective. Community, Environment and Disaster Risk Management, vol. 5, ed. R. Shaw, J.M. Pulhin and J.J. Pereira, 59-79. Bingley: Emerald.

Rose, A. 2004. Economic principles issues and research priorities in hazard loss estimation. In Modeling spatial and economic 
impacts of disasters, ed. Y. Okuyama and S. Chang, 13-36. Heidelberg: Springer.

Royal Government of Cambodia. 2002. National poverty strategy paper. http://web.worldbank.org/WBSITE/EXTERNAL/COUN TRIES/EASTASIAPACIFICEXT/CAMBODIAEXTN/0,,content MDK:20174685 pagePK:1497618 piPK:217854 theSitePK: 293856,00.html. Accessed 10 Jun 2014.

Royal Government of Cambodia. 2009. National strategic development plan update 2009-2013. http://www.ilo.org/asia/whatwedo/ publications/WCMS_145085/lang-en/index.htm. Accessed 10 Jun 2014.

Royal Government of Cambodia and WFP (World Food Programme). 2003. Mapping vulnerability to natural disasters in Cambodia. http://home.wfp.org/stellent/groups/public/documents/ena/wfp034529. pdf. Accessed 10 Jun 2014.

Royal Government of Cambodia and WFP (World Food Programme). 2013. Small-area estimation of poverty and malnutrition in Cambodia. http://www.wfp.org/content/cambodia-small-area-estimation-pov erty-and-malnutrition-april-2013. Accessed 10 Jun 2014.

Sagala, S. 2006. Analysis of flood physical vulnerability case study: Naga city, the Philippines. Master's thesis. International Institute for Geo-Information Science and Earth Observation, Enshedu, the Netherlands.

Santos, J.R. 2006. Inoperability input-output modeling of disruptions to interdependent economic systems. Systems Engineering 9(1): 20-34.

Santos, J.R. 2012. An input-output framework for assessing disaster impacts on Nashville metropolitan region. https://www.iioa.org/ conferences/20th/papers/files/691_20120501071_JoostSantos-IIO ABratislava.pdf. Accessed 10 June 2014.
UNDP (United Nations Development Porgramme). 2010. A "noregrets" risk-based approach to climate-proofing of public infrastructure: Improved national and sub-national planning for resilience and sustainable growth. http://www.adaptationlearn ing.net/sites/default/files/Infrastructure\%20Climate\%20Proofing. pdf. Accessed 10 June 2014.

UNISDR (United Nations International Strategy for Disaster Reduction). 2013. Global assessment report on disaster risk reduction (GAR)-from shared risk to shared value: The business case for disaster risk reduction. http://www.unisdr.org/we/inform/publica tions/33013. Accessed 10 June 2014.

University of Pennsylvania. 2013. Penn world table. http://www.rug. nl/research/ggdc/data/penn-world-table. Accessed 10 June 2014.

Vathana, S., S. Oum, P. Kan, and C. Chervier. 2012. Impact of disasters and role of social protection in natural disaster risk management in Cambodia. http://www.eria.org/http:/www.eria. org/publications/research_project_reports/FY2011/No.8/Chapter_6. pdf. Accessed 10 Jun 2014.

Wahlstrom, M. 2013. Progress and challenges in global disaster reduction. Summary of an address given at Beijing Normal University, 10 January 2013, Beijing China. International Journal of Disaster Risk Science 4(1): 48-50.

World Bank. 2012. Advancing disaster risk financing and insurance in ASEAN member states: Framework and options for implementation. https://www.gfdrr.org/drfiinaseanmemberstates. Accessed 10 June 2014

World Bank. 2014. World development indicators. http://databank. worldbank.org/data/home.aspx. Accessed 10 June 2014. 